\title{
DESCRIPTION OF A NEW WATER MITE SPECIES OF THE GENUS HYGROBATES (ACARI, HYDRACHNIDIA, HYGROBATIDAE) FROM KAMCHATKA
}

\author{
Petr V. Tuzovsky \\ Institute for Biology of Inland Waters, Russian Academy of Sciences, Borok, Yaroslavl Prov., Russia \\ E-mail: tuz@ibiw.yaroslavl.ru
}

\begin{abstract}
A description of a new water mite, Hygrobates kamchatkaensis from the Kamchatka Peninsula is provided.
KEY WORDS: Water mite, Hygrobatidae, Hygrobates, $H$. kamchatkaensis, morphology, larva, deutonymph, female, male.
\end{abstract}

DOI: 10.21684/0132-8077-2017-25-2-143-150

\section{INTRODUCTION}

The goal of this paper is to describe the larva, deutonymph, female and male of a new water mite species of the genus Hygrobates Koch, 1837 from the Kamchatka Peninsula.

Specimens were collected by the author in Azhabachie Lake (Kamchatka). Specimens were not fixed in Koenike liquid. Instead, the slides were made from fresh material. All the specimens were not dissected, thus preserving a natural shape of the body. For several larvae, deutonymphs and adults, the gnathosoma was mounted in the position that allowed investigating pedipalps in the lateral view. To obtain the larvae, the water mites were maintained in laboratory conditions (room temperature, natural daynight sequence). The eggs and larvae, obtained from the female, were kept individually in glass containers, $15 \mathrm{~mm}$ in diameter, and $15 \mathrm{~mm}$ in height.

Idiosomal setae are named according to Tuzovskij (1987): $F c h$-frontales chelicerarum, $F p$-frontales pedipalporum, $V i$-verticales internae, $V e$-verticales externae, $\mathrm{O} i$-occipitales internae, $\mathrm{O} e$-occipitales externae, $\mathrm{Hi}$-humerales internae, $\mathrm{He}$-humerales externae, $H v$-humerales ventralia, $S c i$-scapulares internae, $\mathrm{Sce}$ - scapulares externae, $\mathrm{Li}$-lumbales internae, $\mathrm{Le}$-lumbales externae, $\mathrm{Si}$ - sacrales internae, $\mathrm{Se}$ - sacrales externae, $\mathrm{Ci}$ - caudales internae, $\mathrm{Pi}$ - praeanales internae, $\mathrm{Pe}$ - praeanales externae, $A i$ - anales internae, $A e$ - anales externae.

Furthermore, the following abbreviations are used: P-1-5, pedipalp segments (trochanter, femur, genu, tibia and tarsus); I-Leg-1-5, first leg, segments 1-5 (trochanter, femur, genu, tibia and tarsus) i.e. III-Leg-3=genu of third leg; $\mathrm{C} 1-$ coxal setae located posteromedially on coxa I, C2coxal setae located posterolaterally on coxae I, C3 - coxal setae located anterolaterally on coxae III, C4 - coxal setae located anteriorly on coxae III, L - length; $\mathrm{W}$ - width; $\mathrm{n}=$ number of specimens measured; all measurements are given in $\mu \mathrm{m}$.

\section{DESCRIPTION}

\section{Hygrobates (Hygrobates) kamchatkaensis sp. $\mathbf{n}$.}

Figs. 1-24

Type material. Holotype: female, slide 4647, Russia, Kamchatka Province, Azhabachie Lake, 1 July 1983, leg. P.V. Tuzovskij. Paratypes: 1 female, 1 male, 3 deutonymphs, from some locality and collection date as holotype. Larvae $(n=7)$ were reared from single female (holotype), the duration of the embryonic period was 13 days.

Diagnosis. Larva. Dorsal plate elongate (L/W ratio $1.58-1.70)$, slightly narrowed in anterior half, setae $F c h$ longer than $V i$, tmas on coxae III absent, setae $P e$ slightly longer than $P i$, number of thickened distal setae on legs segments: I-Leg: $1-1-1-$ 0-0, II-Leg: 0-2-3-4-0, III-Leg: 0-2-4-5-0. Deutonymph: integument soft and finely striated; coxal plates I posteriomedial margin convex in shape; setae Fch short, thick; coxal plate IV subrectangular; P-2 ventral margin straight distally forming a right angle, a few denticles covering distal half or $2 / 3$ of ventral surface of segment; genital field with two elongate plates bearing two acetabula and three short, thin setae each, acetabula well separated on each side; excretory pore unsclerotized and situated slightly anteriorly to flanking setae ( $P i$ and $C i$ ), I-Leg-5 with two short subequal distoventral setae; II-IV-Leg-5 with single swimming seta each. Adults: coxal plate IV subrectangular; P-2 ventral margin straight, distally forming a right angle, denticles covering distal $2 / 3$ of ventral surface of segment; P-4 ventral setae close to each other and situated near the middle of segment; I-Leg-5 with two short subequal distoventral setae; II-IV-Leg-5 with single swimming seta each. Female: genital plates elongate, slightly longer than gonopore, medial margin in- 


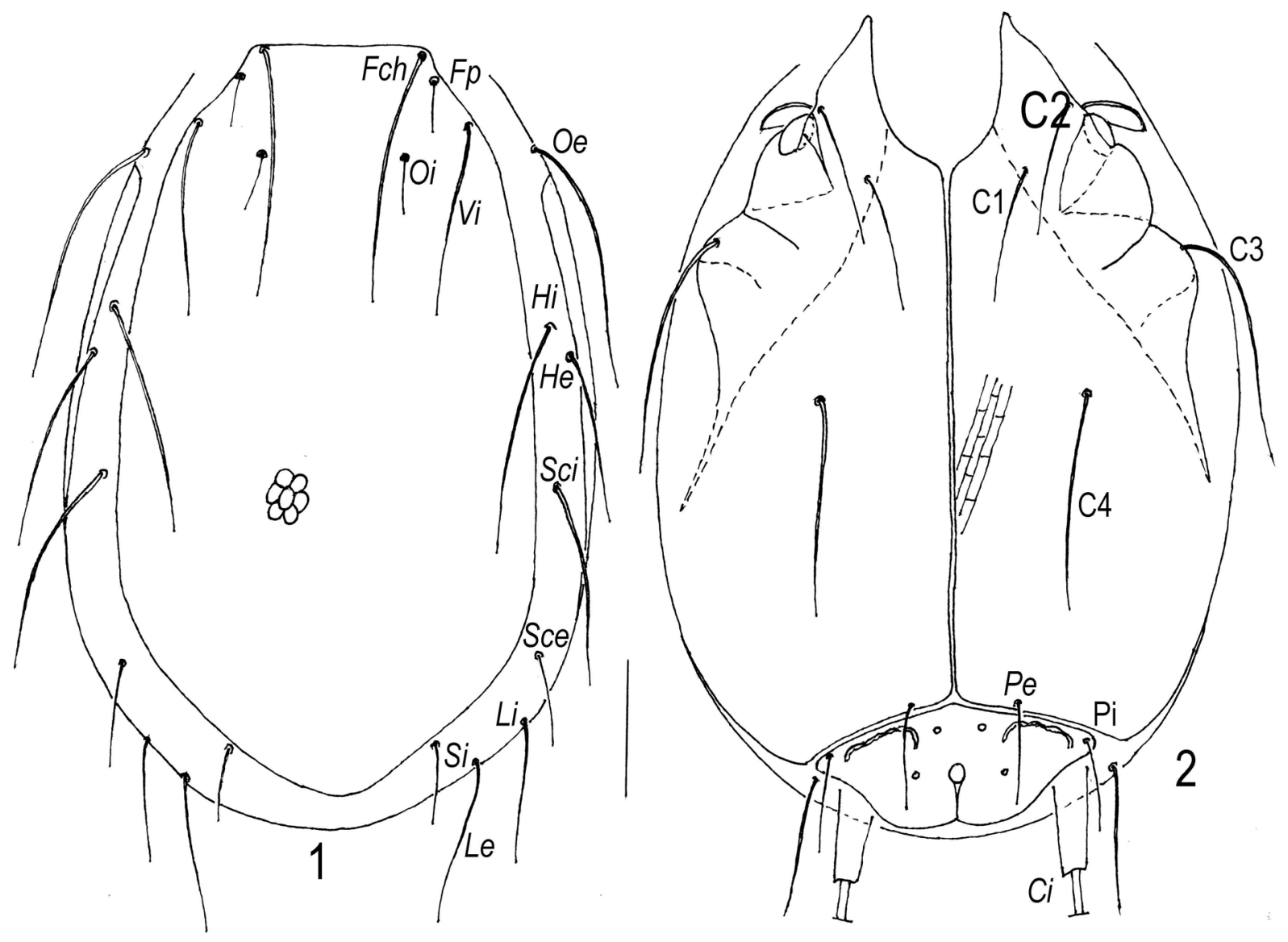

Figs. 1-2. Hygrobates kamchatkaensis sp. n., larva: 1-dorsal view, 2-ventral view. Scale bar $50 \mu \mathrm{m}$.

dented near the center, with 23-27 setae each, acetabula subequal in size and located in obtuse triangle. Male: genital plate wider than long, anterior margin with a knob-shaped projection, posterior margin indented, with a short rounded median projection, with $27-30$ pairs of setae, acetabula $2 / 3$ large on the same level.

Larva. Dorsal plate elongate (L/W ratio 1.58 1.90), in unengorged larvae covering large part of dorsum (Fig. 1), acute anteriorly, slightly narrowed in anterior half posterior end rounded, simple setae ( $F c h$, Vi) long, thick, unequal, trichobothria $(F p, O i)$ short, thin and subequal; $F c h$ longer than $V i$. Eight pairs of setae (Oe, Hi, He, Sci, Sce, Li, Le, Si) situated in soft membrane. Setae $\mathrm{Oe}$ longest, $\mathrm{Hi}$ and $\mathrm{Sci}$ almost subequal in length and longer than the other setae situated in the membrane.

Both of coxal groups separated (Fig. 2). Coxal setae $\mathrm{C} 1$ and $\mathrm{C} 2$ relatively short and subequal, C3 slightly longer than C4. Transverse muscle attachment scar on coxae III absent. Setae $P e$ slightly longer than $P i$. Urstigma relatively large, oval. All coxae with reticulated patterns consisting of elongated cells. Setae $C i$ very long, well thickened, situated on long projection. Excre- tory pore plate wider than long ( $\mathrm{L} / \mathrm{W}$ ratio $0.47-$ $0.50)$, slightly convex anteriorly, W-shaped posteriorly and with muscle attachment scars anteriorly; excretory pore and bases of setae $A e$ on the same level in the center of plate, bases of setae $A i$ located close to the anterior margin; distance between bases of setae $A e-A e$ two times longer than between $A i-A i$.

Capitulum (Fig. 3) elongate with relatively wide base and narrow rostrum. Basal part of capitulum longer than rostrum. Dorsal hypostomal setae longer than ventral ones.

Basal segments of chelicerae fused to each other medially (Fig. 4), with slightly convex lateral margins and straight or slightly concave anterior edges. Chela relatively small, crescent-shaped, with two minute subapical teeth (Fig. 5).

Pedipalps stout (Fig. 6): P-1 very short, without setae; P-2 relatively large, with single dorsal seta near middle of segment; P-3 with a very long, thick lateroproximal seta and short, fine dorsoproximal seta; P-4 with two unequal setae and a massive dorsodistal claw; P-5 small, with one rather long solenidion and unequal simple setae, one of them very short. 

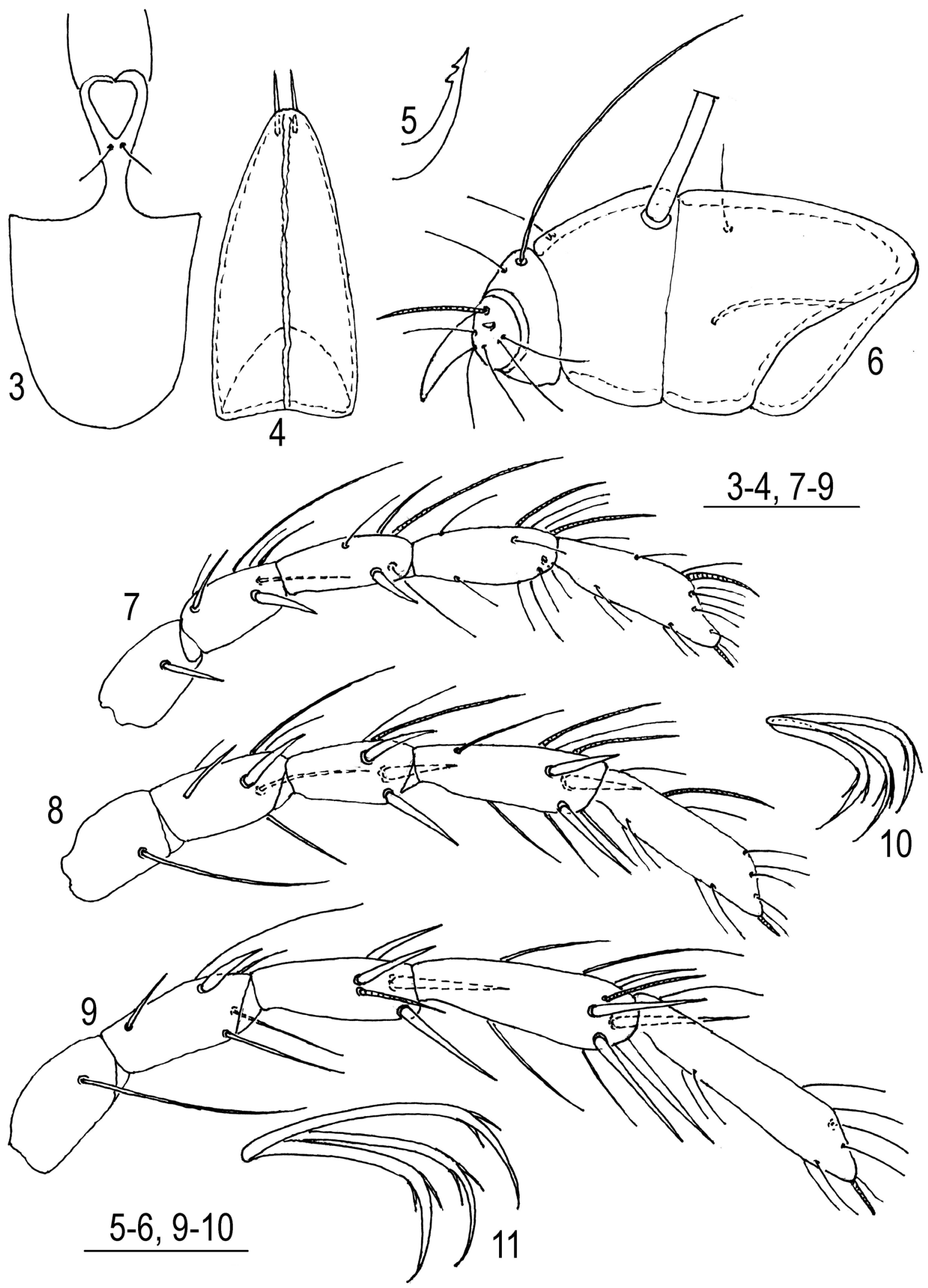

Figs. 3-11. Hygrobates kamchatkaensis sp. n., larva: 3-capitulum, ventral view, 4 -chelicera, dorsal view, 5-distal portion of chela, lateral view, 6-pedipalp, lateral view, 7-Leg I; 8-Leg II; 9-Leg III, 10 - claws of leg I, 11 —claws of leg III. Scale bars $50 \mu \mathrm{m}(3-4,7-9), 20 \mu \mathrm{m}(5-6,9-10)$. 


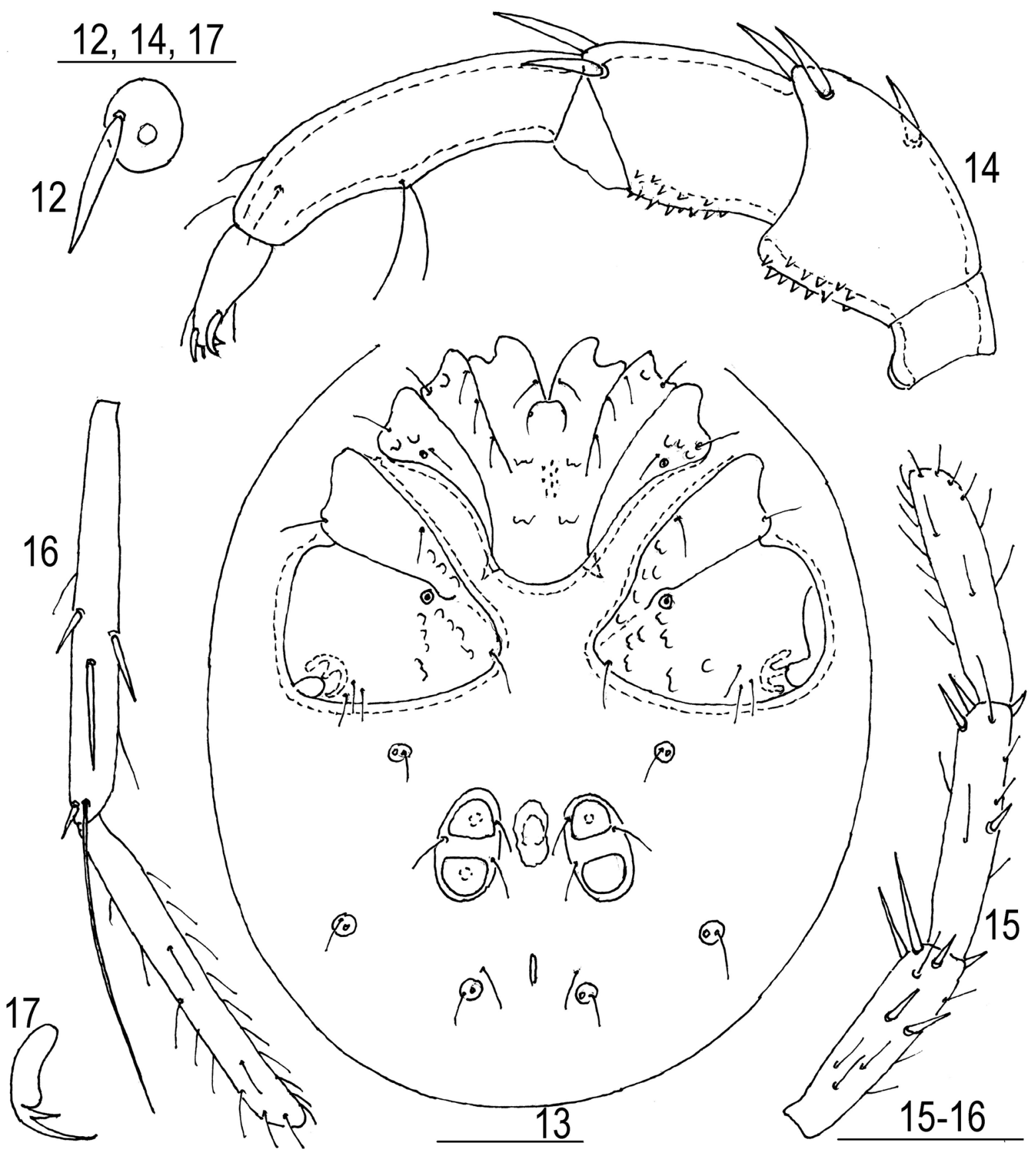

Figs. 12-17. Hygrobates kamchatkaensis sp. n., deutonymph: 12-seta Fch, 13-idiosoma, ventral view 14-pedipalp; 15-I-Leg-4-6; 16, IV-Leg-5-6, 17, claw. Scale bars $50 \mu \mathrm{m}(12,14,17), 100 \mu \mathrm{m}(13,15-16)$.

Shape and arrangement of setae, excluding eupathidia, on legs segments as shown in Figs. 7-9. Number of thickened distal setae from trochanter to tarsus: I-Leg: $1-1-1-0-0$, II-Leg: $0-2-3-4-0$, III-Leg: 0-2-4-5-0. Claws of legs III (Fig.11) larger than claws of legs I and II (Fig. 10).

Measurements, $\mathrm{n}=10$. Dorsal plate L 250 260, W 170-160; setae Fch L 73-85, Vi, Hi, He L 60-70, setae Fp and Oi L 16-20, setae Oe L 80-87; setae $V i$ L 57-65; setae $H i$ L 70-75, setae He L 52-58; setae Sci L 58-74; setae Sce, Li, Le, Se L 35-48; setae Si L 25-32, setae Ci L 180-
200, setae $P i$ L 25-29, setae $P e$ L 35-39, setae C1 and C2 L 35-42, setae C3 L 80-90, setae C4 L 73-85; medial margins of coxae I-III L 175185; hypostomal bay L 41-48; urstigma L 16-19; excetory pore plate L 44-55, W 102-112; capitulum L 89-93; basal segments of chelicerae L 76-83, chela L 16-17; pedipalpal segments (P-1-5) L: 5-6, 28-32, 22-26, 6-7, 5-6; legs segments L: I-Leg-1-5: 28-32, 35-42, 36-39, 44-48, 48-52; II-Leg-1-5: 32-36, 35-39, 38-42, 51-56, 51-58; III-Leg-1-5: 41-45, 41-45, 44$48,60-65,67-71$. 


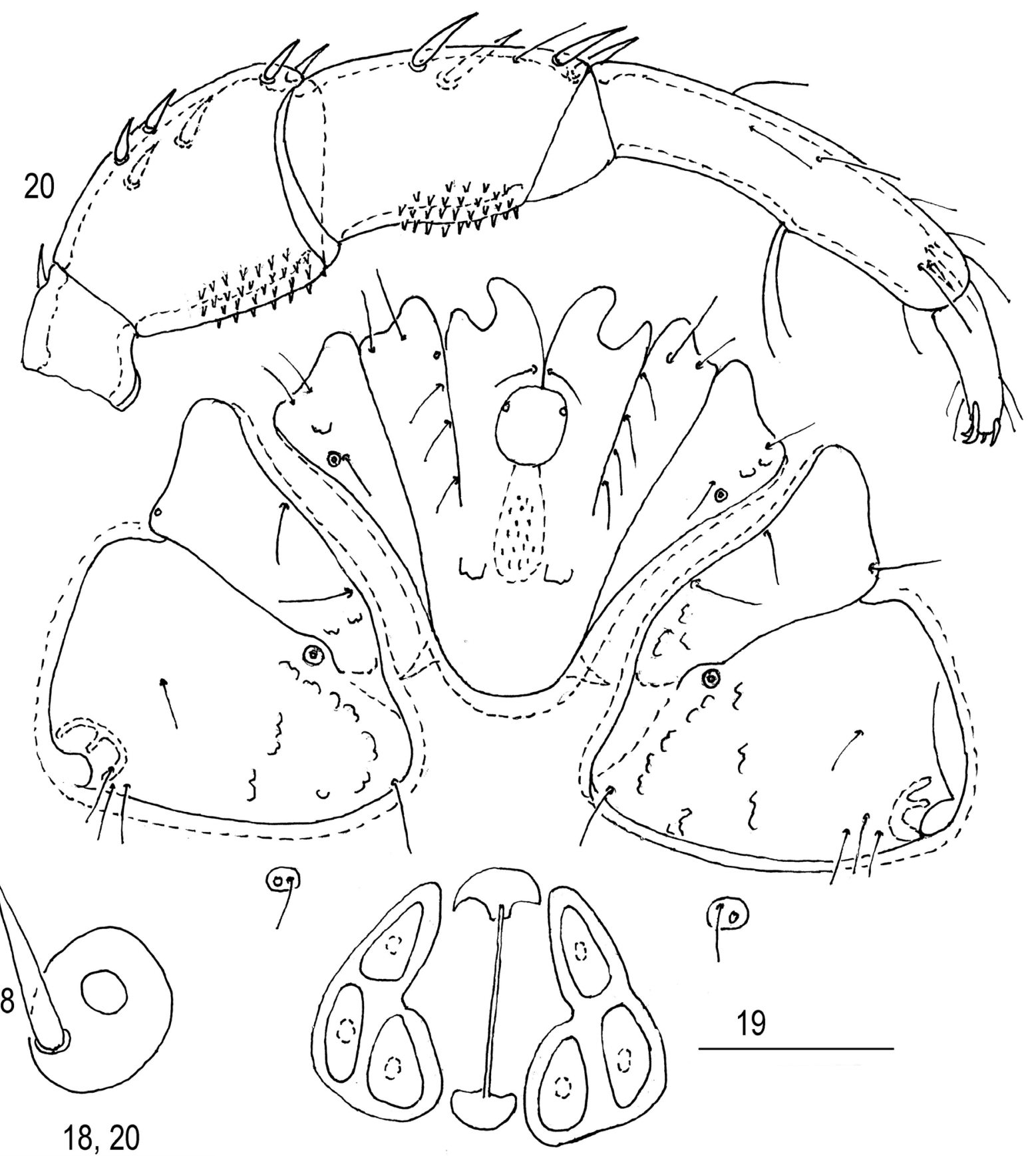

Figs. 18-20. Hygrobates kamchatkaensis sp. n., female: 18 - seta Fch, 19-idiosoma, ventral view; 20-pedipalp. Scale bars $50 \mu \mathrm{m}(18,20), 200 \mu \mathrm{m}(19)$.

Deutonymph. Integument soft and finely striated. Idiosoma oval and somewhat flattened dorsoventrally. Trichobothria $F p, O i$ and setae $P i$ not associated with glandularia, other idiosomal setae associated with glandularia. Setae Fch (Fig. 12) much thicker than other idiosomal setae. Anterior coxal plates with short apodemes, posteromedial margin convexity rounded (Fig. 13). Coxal plate IV subtriangular in shape with rounded medial margin. Genital field with two elongate plates (L/W ratio $1.67-1.85$ ) bearing two acetabula and three short, thin setae each, acetabula well separated on each side, genital sclerite moderately developed and located between the plates. Excretory pore unsclerotized and situated slightly anteriorly to flanking setae $(P i$ and $C i)$.

Pedipalp moderately long (Fig. 14): P-1 without setae, P-2 with one dorsoproximal seta and two dorsodistal subequal setae, ventral margin straight distally forming a right angle, a few denticles covering distal half or $2 / 3$ of ventral surface of segment; P-3 with two dorsodistal thick unequal setae, ventral 

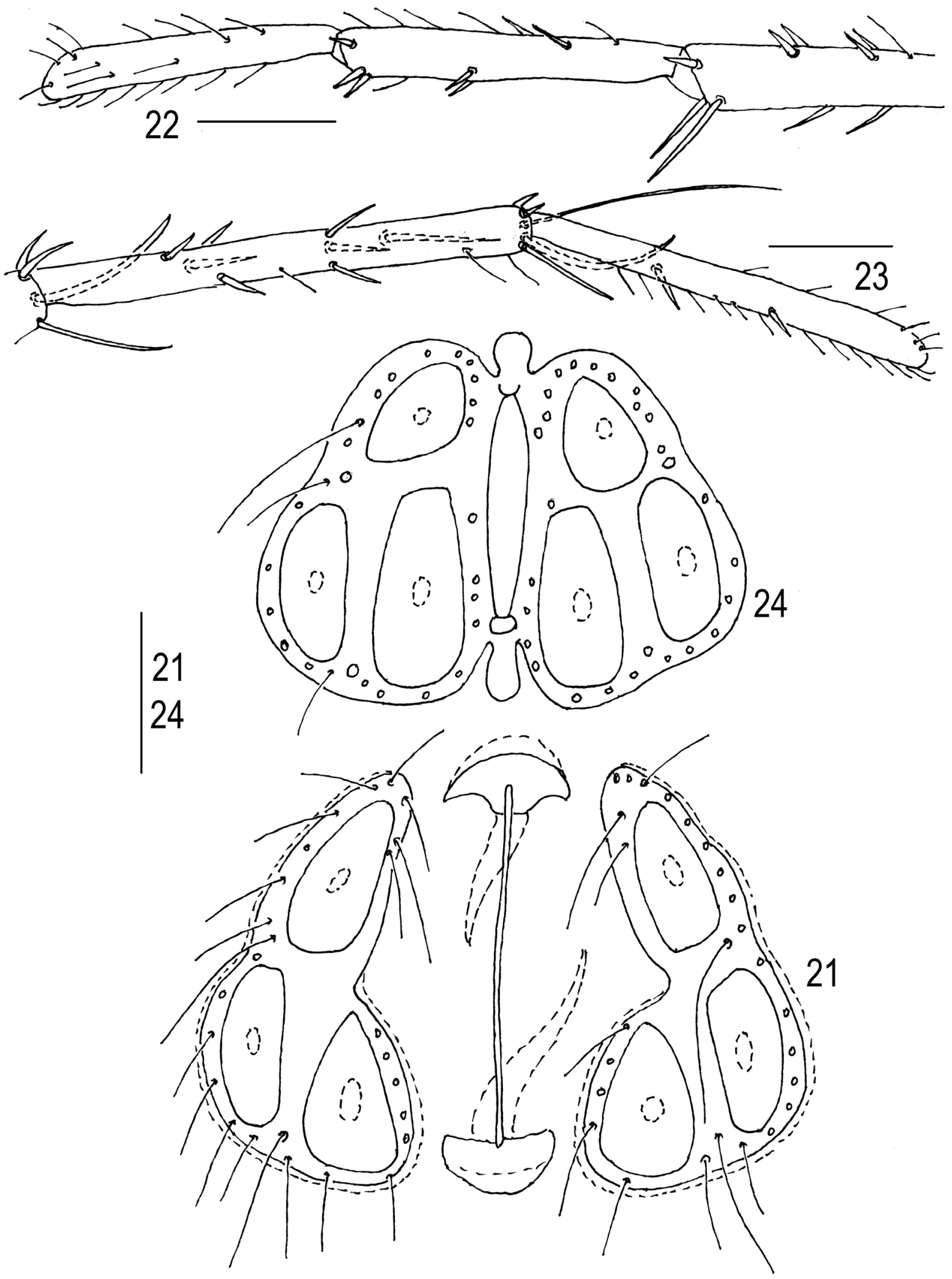

Figs. 21-24. Hygrobates kamchatkaensis sp. n., adult: 21, 24 - genital field, 22-I-Leg-4-6, 23-IV-Leg-5-6;21-23female, 24-male. Scale bars $100 \mu \mathrm{m}$.

margin slightly convex distally, with a few denticles covering distal half or $2 / 3$ of segment; P-4 ventral setae on the same level near middle of segment.
Shape and arrangement of setae on terminal segments of legs I and IV as shown in Figs. 15-16. I-Leg-5 with two short subequal distoventral setae. 
II-IV-Leg-5 with single swimming seta each. Claws in all legs with long external clawlet and short internal one, lamella with concave ventral margin (Fig. 17).

Measurements, $n=3$. Idiosoma L 450-510; seta Fch L 30-37; coxal plates I+capitulum mL 160175; genital plates L 72-80, W 38-48, genital acetabula (ac-1-2) L/W 24-30/27-36, 30/30-42; pedipalp segments (P-1-5) L: 20-24, 60-66, 48-54, 84-90, 29-31; legs segments L: I-Leg-1-6: 42-48, 48-55, 65-72, 95-108, 105-112, 108-115; IILeg-1-6: 42-48, 50-55, 72-78, 105-115, 128-133, 120-125; III-Leg-1-6: 45-50, 54-66, 78-90, 125-138, 150-162, 144-150; IV-Leg-1-6: 78-90, 72-78, 108-115, 155-168, 174-180, 150-162.

Adults. Integument soft and finely striated. Setae Fch (Fig. 18) thicker than others idiosomal setae. Posteromedial margin of coxal plates I rounded (Fig. 19). Coxal plate IV subtriangular in shape, with a slightly nose-rounded protruding medial margin.

Pedipalp (Fig. 20) moderately long: P-1 with single dorsodistal seta; P-2 usually with six thick dorsal setae, ventral margin straight, distally forming a right angle, denticles covering distal $2 / 3$ of ventral surface of segment; P-3 with two dorsoproximal, two dorsodistal thick setae and with single seta ventral margin straight or slightly convex in distal half, denticles covering distal $2 / 3$ of ventral surface segment; P-4 ventral setae close to each other and situated near the middle of segment.

Shape and arrangement of setae on terminal segments of legs I and IV as shown in Figs. 22-23, respectively. I-Leg-5 with two short subequal distoventral setae. II-IV-Leg-5 with swimming seta each.

Female. Genital plates elongate $(\mathrm{L} / \mathrm{W}$ ratio 1.7-2.0), slightly longer than gonopore, medial margin indented near the center, with 23-27 setae each, acetabula subequal in size and located in obtuse triangle (Fig. 21).

Measurements ( $\mathrm{n}=2)$. Idiosoma L 1,300-1,600; seta Fch L 35-38; coxal plates I+capitulum mL 285-315; genital plates L 205-213, W 100-125, genital acetabula (ac-1-3) L/W 73-75/37-38, 75-80/30-38, 75-88/55-63; cheliceral segments L: base 285-315, chela 150-163; pedipalp segments (P-1-5) L: 37-45, 160-165, 105-115, 175-188, 55-63; legs segments L: I-Leg-1-6: 775-88, 125-130, 160-165, 230-240, 250-265, 225-230; II-Leg-1-6: 80-90, 135-145, 185-200, 260-275, 300-315, 260-275; III-Leg-1-6: 100105, 155-175, 210-225, 300-340, 350-375, 300-325; IV-Leg-1-6: 195-205, 185-190, 275290, 380-400, 385-400, 325-360.
Male. Genital plate (Fig. 24) wider than long, anterior margin with a knob-shaped projection, posterior margin indented, with a short rounded median projection, with $27-30$ pairs of setae, acetabula in a triangular position, ac-2/3 much larger than ac-1 and on the same level.

Measurements $(\mathrm{n}=1)$. Idiosoma L 1,100; seta Fch L 45; coxal plates I+capitulum mL 350; genital plate L 185, W 250, genital acetabula (ac1-3) L/W 55/42, 87/37, 100/50; cheliceral segments L: base 250 , chela 125 ; pedipalp segments (P-1-5) L: 37, 120, 87, 150, 50; leg segments L: ILeg-1-6: 75, 100, 140, 195, ?, ?; II-Leg-1-6: 87, 112, 162, 235, 260, 360; III-Leg-1-6: 87, 125, 180, 275 , ?, ?; IV-Leg-1-6: 160, 160, ?, ?, ?, ?.

Differential diagnosis. The new species is similar to Hygrobates nigromaculatus group, which included the following species: $H$. nigromaculatus Lebert, 1879, H. octoporus Daday, 1905 and H. setosus Besseling, 1942. P-2 ventral margin in all named species straight and without any distoventral protrusion or projection. The larva and deutonymph in $H$. octoporus are unknown. Distinctions between these species in the identification keys are given.

\section{Key to species of the Hygrobates nigromaculatus group}

\section{Larvae}

1 (2) Transverse muscle attachment scar on coxa III present (Tuzovskij 2017) H. setosus Besseling, 1942

2 (1) Transverse muscle attachment scar on coxa III absent

3 (4) Dorsal plate broad with convex lateral margins, I-Leg-2/3 with two heavy distal setae each (Tuzovskij 2017)

.H. nigromaculatus Lebert, 1879

4 (3) Dorsal plate relatively narrow with parallel lateral margins (Fig. 1); I-Leg-2/3 with single heavy distal seta each (Fig. 7).

..H. kamchatkaensis sp. n.

\section{Deutonymphs}

1 (2) II-IV-Leg-5 with one swimming seta each (Fig. 16) .H. kamchatkaensis sp. $\mathrm{n}$.

2 (1) II-IV-Leg-5 without swimming setae

3 (4) I-Leg-5 with two unequal distoventral setae (Tuzovsky 2017)

.H. nigromaculatus Lebert, 1879

4 (3) I-Leg-5 with two subequal distoventral setae (Tuzovskij 2017)

H. setosus Besseling, 1942 


\section{Adults}

1 (2) Genital field with four pairs of acetabula. H. octoporus Daday, 1905

2 (1) Genital field with three pairs of acetabula

3 (4) II-IV-Leg-5 with single swimming seta each (Fig. 23) H. kamchatkaensis sp. n.

4 (3) II-IV-Leg-5 without swimming setae

5 (6) Both sexes: I-Leg-5 with two short unequal distoventral setae. Females: Median length of the coxal plates $\mathrm{I}+$ capitulum relatively short $\mathrm{L}$ 300-320 $\mu \mathrm{m}$, genital plates short L 150-175 $\mu \mathrm{m}$. Males: Ejaculatory complex proximal chamber subrectangular, with straight anterior margin, pair of the rudimentary proximal horns extending to the anterior margin of the proximal chamber; median length of coxal plates I+capitulum L 270-290 $\mu \mathrm{m}$ (Tuzovskij 2017)

H. nigromaculatus Lebert, 1879

6 (5) Both sexes: I-Leg-5 with two short subequal distoventral setae. Females: Median length of the coxal plates I+capitulum comparatively long L 330-360 $\mu \mathrm{m}$, genital plates relatively long L 205-230 $\mu \mathrm{m}$. Males: Ejaculatory complex proxi- mal chamber oval with convex anterior margin, a pair of rudimentary proximal horns not reaching to the anterior margin of proximal chamber, median length of coxal plates I+capitulum L 330-345 $\mu \mathrm{m}$ (Tuzovskij 2017)........ H. setosus Besseling, 1942

Etymology. The species is named after the region where it was collected (Kamchatka).

Habitat. Standing waters.

Distribution. Asia (Russia: Kamchatka peninsula).

\section{ACKNOWLEDGEMENTS}

The author expresses his sincere gratitude to anonymous referees for reviewing of the paper.

\section{REFERENCES}

Tuzovskij, P.V. 1987. Morphology and Postembryonic Development in Water Mites. Nauka, Moscow, 172 pp. [In Russian]

Tuzovskij, P.V. 2017. On the systematic of the water mites Hygrobates nigromaculatus Lebert, 1879 and H. setosus Besseling, 1942 (Acari, Hydrachnidia, Hygrobatidae). Zootaxa, 4277 (1): 17-31. 